\title{
Approaches to Monitoring and Managing Indigenous Australian Coastal Cultural Heritage Places
}

\author{
Michael J. Rowland ${ }^{1}$, Sean Ulm ${ }^{1}$ and Meredith Roe $^{2}$ \\ 1 College of Arts, Society and Education, James Cook University, PO Box 6811, Cairns QLD 4870, Australia \\ rowlandmk@iprimus.com.au, sean.ulm@jcu.edu.au \\ 2 Department of Aboriginal and Torres Strait Islander and Multicultural Affairs, GPO Box 2454, Brisbane QLD 4001, \\ Australia meredith.roe@datsima.qld.gov.au
}

\begin{abstract}
Australia's coastal zone contains a diverse range of cultural heritage places. They are, however, negatively impacted by a multitude of natural and cultural factors. Currently there are few robust site monitoring programmes that focus on identifying the causes and directions of change in the coastal zone and the impacts that these changes have on heritage places. With case studies from Queensland, we outline and evaluate a number of potential approaches to coastal monitoring. They range from localised but inexpensive combinations of anecdotal observations coupled with geoindicators, to the use of more recent and sophisticated technologies such as LiDAR (Light Detection and Ranging) remote sensing. We also propose there is a need to establish cooperative information data sharing arrangements in Australia for coastal monitoring studies.
\end{abstract}

\section{Introduction}

Coastlines, marine resources and ultimately seaborne contacts have played a critical role in human development resulting in a rich legacy of cultural heritage places on the world's coastlines (Bailey 2004). These coastlines continue to be an important focus of human settlement and consequently a wide range of natural and cultural factors have and continue to impact adversely on coastal heritage places (e.g. Hassler 2006; Rowland 2010; Rowland and Ulm 2012). Cyclones, storms and storm surges, and wave and tidal action, for example, have major impacts on dune systems while sand and coral mining and the spread of tourist, residential and industrial developments have direct impacts on sites resulting in unregulated loss or salvage (Fitzpatrick et al. 2006). In recent years evidence that humans are warming the world's climate and subsequently causing a rise in sealevels (Parry et al. 2007), has drawn attention to the potential increased impact of sea-level and related changes on coastal areas. Numerous studies have used future climate change projections to indicate potential impacts of climate change on a number of coastal environmental and cultural features. We emphasise that these are projections based on certain assumptions and computer models and accept this as a valid approach to determining potential impacts on coastlines and cultural heritage places. However, we also stress that regardless of projected or potential sea-level change attributed to anthropogenic global warming there is a critical need to develop methods to measure short- and long-term humanand naturally-induced impacts on the coast before effective decisions can be made concerning the short- and long-term management of cultural heritage places (McIntyre-Tamwoy and Buhrich 2012; Rowland 2008). We are therefore not primarily concerned in this paper with climate change per se but with a range of environmental and cultural changes in general and methods of measuring and monitoring the impact of those changes in the coastal zone.

Currently in Australia, short- and long-term monitoring programmes that might identify the causes and directions of change and impacts on coastal cultural heritage places are rare. Where such studies have occurred there has been little coordination and sharing of information across heritage jurisdictions. At this point in time we concur with the view expressed more generally by Jones (2003:198) that there is a poor record of site monitoring, inadequate protocols on when to intervene and limited professionalism in the area of site management. We outline a number of approaches to overcoming some of these issues in the coastal zone.

We discuss, with examples, a number of approaches to measuring the impacts of climate and sea-level change on cultural heritage places. These range in scale from the localised and cost-effective to the broader scale and more complex. We discuss the use of LiDAR as a more complex and expensive but accurate way of measuring long-term trends in coastal change. We also argue that there is a need to establish a national focus relating to site management in the coastal zone so that the information may be more efficiently and effectively shared between jurisdictions. We highlight the need to align cultural heritage management methodologies more closely with the work of other coastal zone researchers and managers. Our examples are from the Queensland coast but are applicable to the Australian coastline in general.

\section{The Australian and Queensland Coastal Zones}

The Australian coastal zone spans $9^{\circ}$ to $42^{\circ} \mathrm{S}$ through extensive and diverse tropical and temperate environments. It comprises reefs, islands, parts of the continental shelf, estuaries, tidal flats, coastal sand dunes and the coastal land margin incorporating a coastline in excess of 60,000km (Department of Resources, Energy and Tourism 2010). Over $80 \%$ of Australia's population lives in the coastal zone (about 22 million in 2010 and an estimated 36 million by 2050) (Commonwealth of Australia 2010) so that human impacts are significant, widespread and diverse. Australian beaches are exposed to tides ranging from less than $1 \mathrm{~m}$ to $11 \mathrm{~m}$ and to wave energy ranging from very low seas to the world's most persistent and energetic swell environments (Short and Woodroffe 2009; Voice et al. 2006:1). Cyclones, wave height and tidal velocity impact at various intensities on 
the coastline. The impact of climate and sea-level change on coastal systems is therefore likely to be significant but difficult to predict over such a large and diverse area (e.g. Church et al. 2008a, 2008b; Cowell et al. 2006; Hunter 2010; Nicholls 2002). Sea-level change due to vertical crustal adjustment to changes in ice and water loading must also be considered (Church and White 2006; Forbes and Liverman 1996:179).

The Queensland coastline which is the focus of our case studies extends over $13,000 \mathrm{~km}$ and comprises diverse sandy beaches, rocky headlands, low-lying mud and sand islands, coral atolls and rocky islands (Figure 1). On the Queensland coast, 66\% of beaches are gently sloping sandy beaches, often backed by beach ridge plains which would have been highly attractive areas for Aboriginal occupation. Global warming is projected to lead to a sea-level rise of $0.26-0.79 \mathrm{~m}$ by 2100 (Queensland Climate Change Centre of Excellence 2011:2). Other projections include: changes in the regional and local frequency of tropical cyclones, an increase of over $0.1 \mathrm{~m}$ in storm surge height resulting from changes in cyclone behaviour, an increased frequency of extreme sea-level events and increased coastal erosion. All of these factors are likely to impact on cultural heritage places.

\section{The Australian Coastal Archaeological Record}

We are unable to determine the proportion of the Australian or Queensland coast that has been surveyed for archaeological sites. Cane's (1997:55) review for the entire Australian coast listed 30,000 recorded sites but he suggested that the real figure may be closer to 60,000. We recognise the importance of his review but suggest that the figure for number of sites might be considerably higher. A study of the South African coastline (3000km) indicated that less than $5 \%$ of the coastal zone had been searched for archaeological sites of which less than $1 \%$ had been systematically surveyed (Coetzee and Kaplan 1996:364) and we would expect the coverage to be broadly similar for Australia. As a first step in site monitoring we recommend that state heritage bodies should produce maps of the coast indicating those areas that have or have not been surveyed together with numbers and types of sites located. Past, present and future cultural and environmental variables likely to impact on the coastal zone should also be mapped.

Indigenous archaeological sites were present on the Australian coast from the time of initial settlement, though early sites are rare due to the destructive impacts of sea-level rise associated with the end of the last ice age around 10,000 years ago (Ulm 2011). As a result of relative sea-level stabilisation in the Holocene, sites belonging to that period are more numerous but there was variability around the coastline with the formation and/or destruction of coastal archaeological sites reflecting a complex interplay of local and sub-regional geomorphic changes, sea-level changes, sediment substrate evolution and human social behavioural and economic scheduling. Subsequently, cyclones, storms, tsunamis, sea-level change, climate change and the impacts of human development have continued to impact on the archaeological record (see Rowland and Ulm 2012). The intensity of cyclones, waves and tides for the Queensland coast are shown in Figure 2.

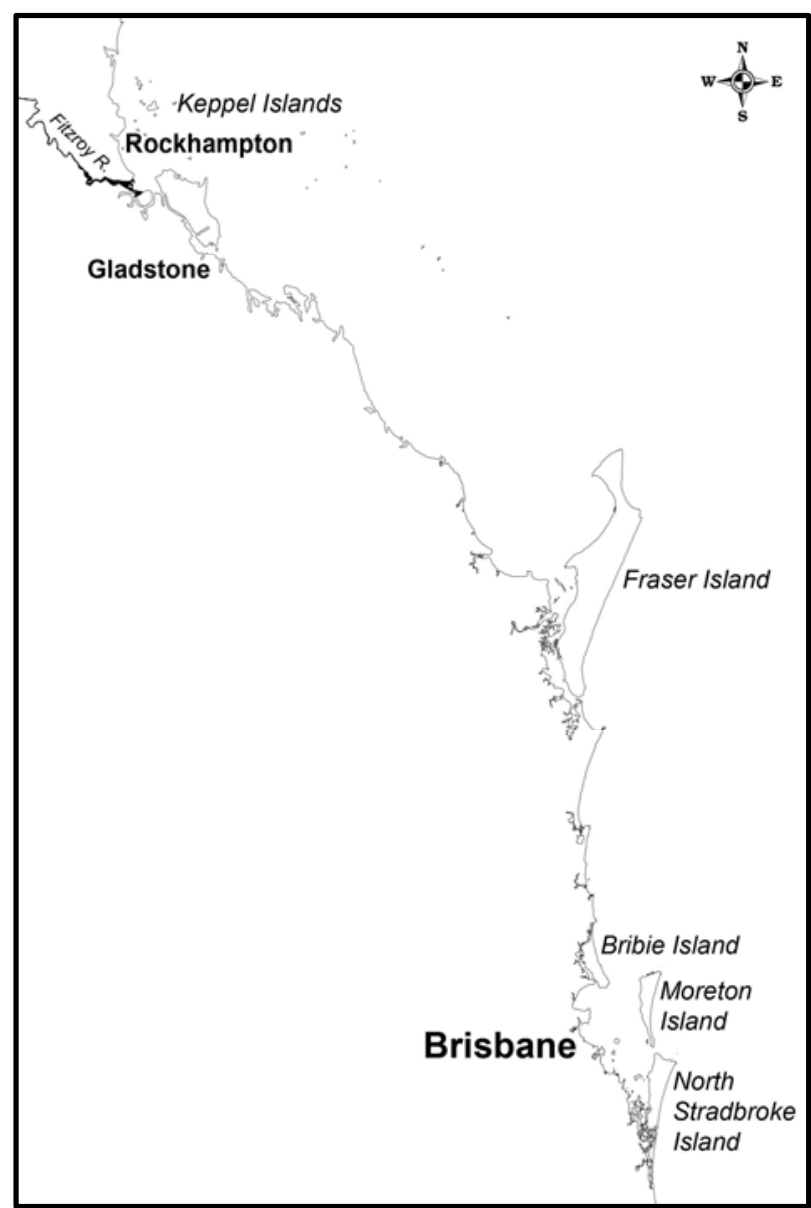

Figure 1. Location of places mentioned in the text.

Complex changes have occurred and will continue to occur in the coastal zone whether caused by normal climate variation or anthropogenic induced warming and will impact on both Aboriginal and European places. Unfortunately with rare exceptions (e.g. Bird 1992, 1995; Pearce 2006; Przywolnick 2002) archaeologists have not yet begun to monitor these potential changes and impacts. It is important to keep in mind that while sea-level may rise or fall by only a few millimetres a much broader area of coastal geomorphology may be impacted (FitzGerald et al. 2008). For example, rising sea-levels may inundate low-lying coastal regions and result in the redistribution of sediment along sandy coasts. The coastal morphology of some areas may be completely reconfigured by these changes.

\section{Approaches to Management and Monitoring}

The management and monitoring of coastal heritage sites in Australia has not been widely discussed and there has been little if any coordination between the various studies (but see Aboriginal Affairs Victoria 2000; Bonhomme and Buzer 1994; Cane 1997; Clark and Hope 1985 [see follow up study by ANU Heritage 2007]; Smith 1998; Snelson et al. 1986; Watson 1993; Zallar et al. 1979). The international literature is more comprehensive and there have been some attempts to coordinate the measurement of key variables (e.g. Bhattacharyya et al. 2010; Britsch and Smith 1989; Crowell et al. 1991; Davis et al. 2000; Fitzpatrick et al. 2006, Hamel and Jones 1982; Lewis 2000; Lynott 1989; Macphail et al. 2010; Moore 2000; Nickens 2001; The Getty Conservation Institute 2003; Thieler and Danforth 1994a, 1994b; Thorne 2004; 


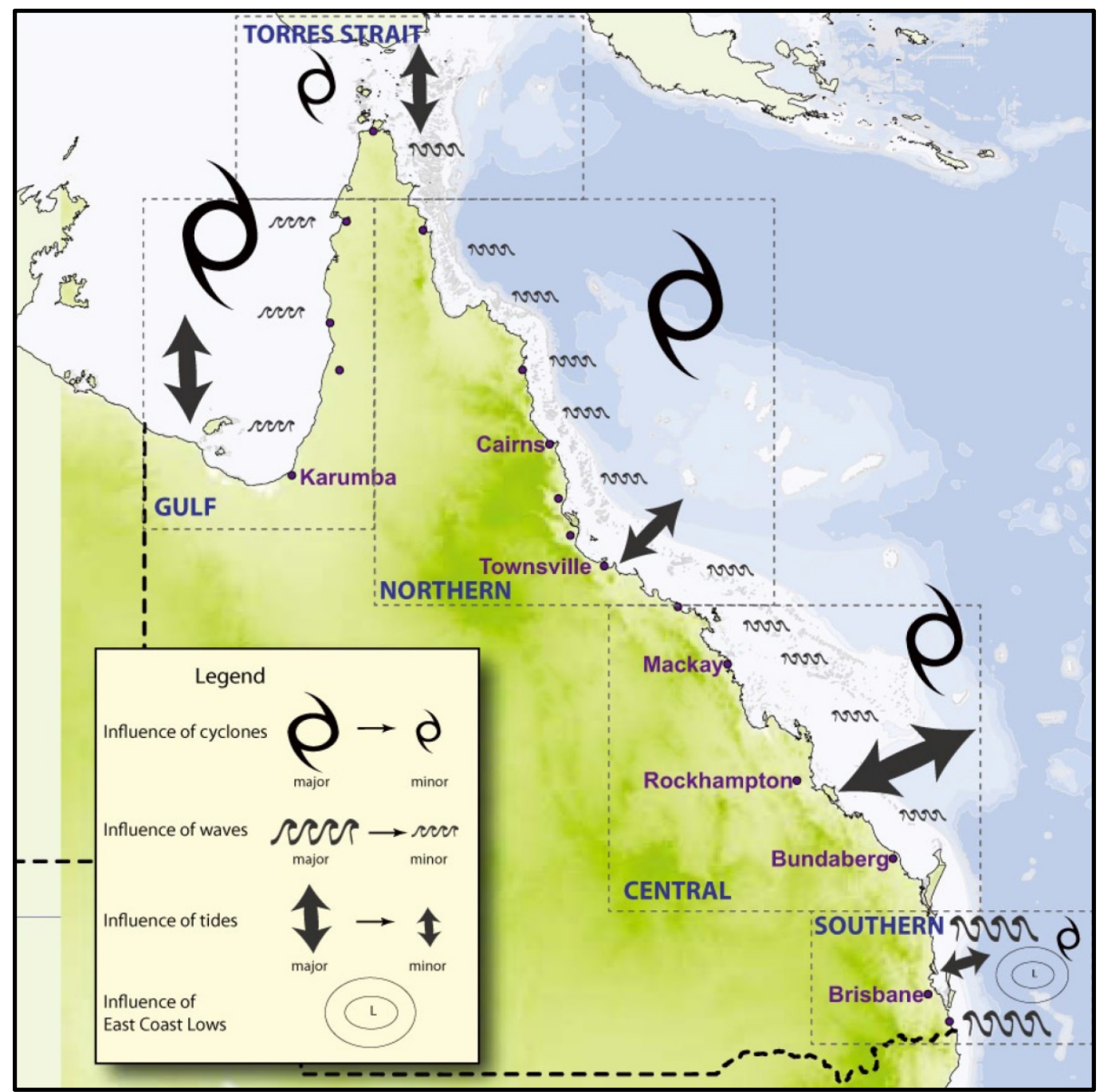

Figure 2. Impact of cyclones, waves, tides and East Coast Lows along the Queensland coast (Queensland Climate Change Centre of Excellence 2011:Figure 11).

Turnbaugh 1978; Williams 2004). The management of coastal sites is challenging due to the wide range of potential impacts that must be considered and also due to the critical issues of scale and cost (for a brief but useful review see Sullivan 1989). There is an extensive literature on methods of dune stabilisation, but the methods only rarely take into account the specific needs of archaeological site protection (Snelson et al. 1986:25). These methods have been developed by beach protection authorities and have rarely been used by cultural heritage management authorities. In the following sections we provide examples of approaches to monitoring change in the coastal zone with examples from the Queensland coast. We commence with an example using general observations and introduce the use of geoindicators and the more recent and powerful LiDAR.

\section{General Observations and Anecdotal Information}

A cost effective but limited approach to monitoring involves the use of general observations and anecdotal information. Rowland (2008), for example, has previously summarised anecdotal observations and other information collected over a period of 30 years in identifying the factors causing damage to coastal archaeological sites on the Keppel Islands off the central Queensland coast. Based on these observations it was apparent that the primary cause of damage over the last 5000 years on the Keppel Islands was due to the long-term action of wind and waves. This 'normal' process of wind and water erosion has been exacerbated in recent times by natural and human-induced vegetation removal. Introduced sheep, goats and possums have been a major source of vegetation destruction on the islands while, contrary to expectations, tourists have probably had a more limited impact on most sites. Stochastic events, such as cyclones, associated storm surges and flood discharges from the nearby Fitzroy River have also had significant impacts.

Rowland (2008) also used geoindicators to measure changes in the coastal zone of the Keppel Islands. Geoindicators are measures (magnitudes, frequencies, rates and trends) in geological processes and phenomena occurring at or near the earth's surface which are subject to changes that are significant in understanding environmental change over periods of 100 years or less. They measure both catastrophic events and those that are more gradual, but evident within a human lifespan. They measure what is happening in the environment, why is it happening and what impacts it is having (see Berger and Iams 1996 for details). Geoindicators provide a higherorder level of measuring change in coastal processes but at a scale relevant to the management of heritage sites (see Rowland 2008 and Daly 2011 for further details). 


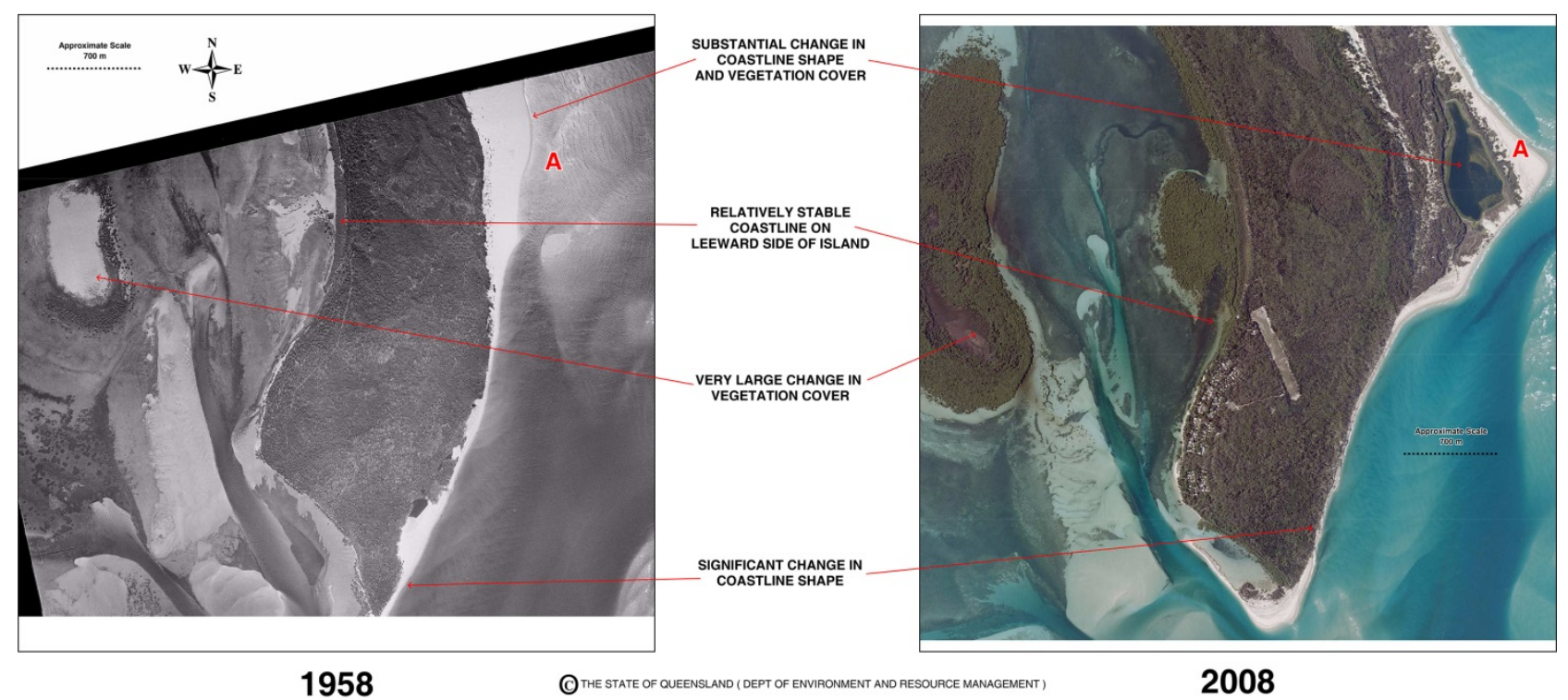

Figure 3. Southern Moreton Island showing sand movement and vegetation change between 1958 and 2008 (data supplied by Department of Natural Resources and Mines, The State of Queensland).

Aerial photographs have also been used to indicate trends in coastal areas. Aerial photos have been used in archaeology since 1880 (Reeves 1936) with increasing sophistication in recent years (e.g. Risbol et al. in press; Verhoeven et al. 2012). Here we provide an example where aerial photographs covering a limited time span (1958 and 2008) and a small area of the southern section of Moreton Island can be used to interpret coastal trends that can assist in interpreting the potential pattern of site distributions (Figure 3). This area of Moreton Island shows a variable pattern of change in coastal morphology. A number of changes in both the pattern of sand movement and vegetation can be recognised over a relatively short period of time. For example, the area marked 'A' on Figure 3 has very recently been built up by sand movement and has become vegetated. The area was low-lying sand flats in 1958 but had built up and was vegetated by 2008. If an archaeological survey were to be undertaken in the area today no archaeological sites are likely to be found since despite appearing to be wellvegetated this is in fact a recent land surface.

A further example again using aerial photographs covering a limited time span shows the location of a number of sites recorded by Ponosov (1964) in 1963 on North Stradbroke Island (Figure 4). It is apparent from the aerial photograph (1965) on which these sites are marked that the dune systems at this time were very exposed. We are currently unable to determine when this erosion may have occurred. However, it may account for the high number of sites (i.e. good site visibility) recorded by Ponosov at the time in this area. It is then apparent, from overlaying the sites on a 2008 aerial photograph that much of the area has revegetated in the intervening period. If fieldwork were undertaken in the area today it might be possible to conclude that many of the sites had been destroyed (which they may have been) since sand mining has been a high level activity on the island. Alternatively, it may be possible that sites have been recovered and revegetated.

The limited use of aerial photographs and anecdotal information on Keppel Islands, Moreton Island and
Stradbroke Island could not be used to draw detailed conclusions about coastal changes and impacts on sites in these areas. However, it appears that most of the changes identified could be attributed to 'normal' changes in climate patterns and increasing human impacts. At present none of the changes could be attributed to the impact of sea-level change related to accelerated global warming. However, the application of basic geoindicators such as those used on the Keppel Islands should in the future enable clearer trends to be identified. Using geoindicators is an inexpensive means of identifying some broad trends.

\section{Predictive Modelling Using LiDAR}

Predictive modelling studies incorporating sea-level changes based on IPCC projections indicating the potential impacts of sea-level rise have been undertaken for a number of coastal areas of the world, including Australia (e.g. Abuodha and Woodroffe 2010; Akumu et al. 2010; Ghilardi and Desruelles 2008; Kvamme 1999; McInnes et al. 2013; Stevens and Collins 2011; Zhang et al. 2004). These are important studies but need to be coupled with long-term monitoring to determine what changes are actually occurring on the coast.

An approach to mapping with considerable potential to monitor the short- and long-term extent and direction of coastal changes and therefore impacts on coastal heritage sites is the application of LiDAR (Light Detection and Ranging) remote sensing (see Hesse 2010 for a useful introduction; see also Chase et al. 2011). Ground-based fixed LiDAR instruments or those attached to aircraft or satellites fire rapid pulses of light at the landscape and a sensor mounted on the instrument measures the amount of time taken for each light pulse to bounce back. Because light moves at a constant and known speed, the LiDAR instrument can then calculate the distance between itself and the target with high accuracy. It is therefore able to build up a complex picture of the terrain and landscape features it is measuring (CSIRO 2013). For example, it is possible to model sealevel rise impacts on coastal features at the sub-metre scales outlined in IPCC reporting (Gesch 2009). 


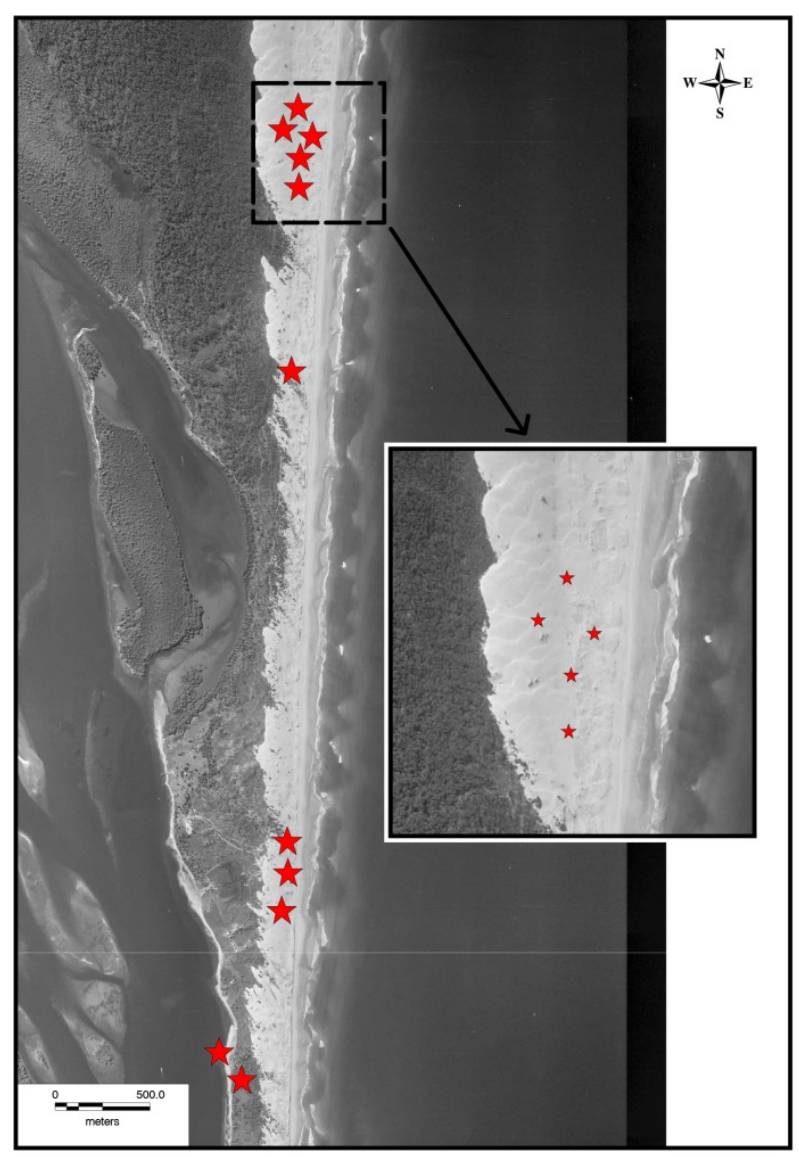

1965

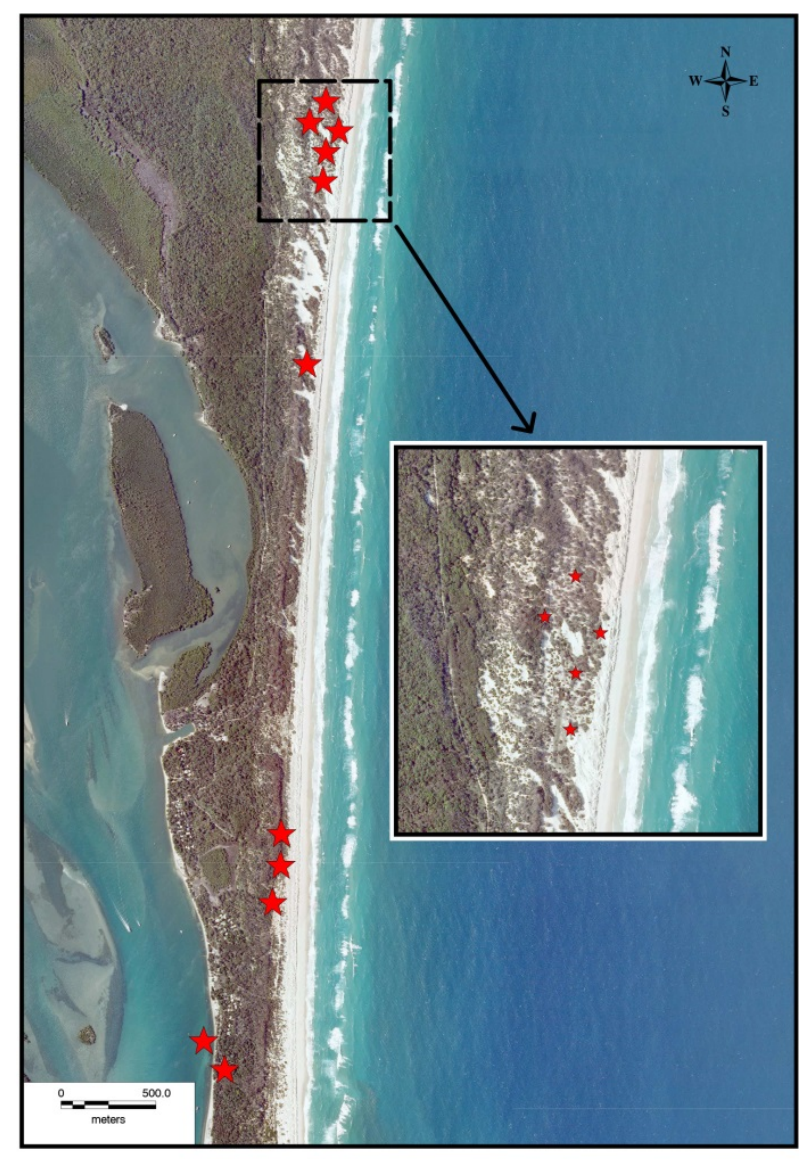

2008

Figure 4. Southern Stradbroke Island showing sand movement and vegetation change between 1965 and 2008. Stars show location of sites recorded by Ponosov (1964) (data supplied by Department of Natural Resources and Mines, The State of Queensland).

LiDAR was introduced into archaeology in 2002 (see Challis et al. 2011a, 2011b; Hesse 2010) and its potential use in Australian archaeology has been recently recognised (McIntyre-Tamwoy and Buhrich 2012). It has been used in mapping geomorphic events and coastal evolution to a high degree of accuracy (e.g. Bull et al. 2010; Hugenholtz et al. 2012; Irvine-Fynn et al. 2011; Oskin et al. 2012; Revell et al. 2002; Sallenger et al. 2003; Shrestha et al. 2005; Stockdon et al. 2002; White and Wang 2003). LiDAR has the potential to date the age of beaches (e.g. Yang and Teller 2012) and to identify land vulnerable to sea-level rise (Gesch 2009; McInnes et al. 2013). LiDAR has been used to map the impacts of mining activities (Kerfoot et al. 2012; Yousef et al. 2013) which could be usefully coupled with archaeological mapping on many sections of the Australian coast impacted by mining. It has been applied to a wide and increasing range of cultural heritage issues outside of Australia (Bennett et al. 2012; Bernardini et al. 2013; Challis et al. 2011a, 2011b; Gontz et al. 2011; Johnson and Ouimet 2014; Ladefoged et al. 2011; Maio et al. 2012). New and more sophisticated versions of the technology continue to be developed (Corns and Shaw 2009). We briefly introduce LiDAR here together with other techniques as an introduction to the potential of these methods for site identification, management and monitoring of coastal cultural heritage sites.

Figure 5 shows the distribution of sites recorded since 1973 on Bribie Island, southeast Queensland by Stockton
(1973) and others. These were recorded variously as middens, artefact scatters and campsites. Overlaying a $1 \mathrm{~m}$ contour using LiDAR data as an approximate height of sea-level rise by 2100 demonstrates that at least two sites (marked A and B) would be completely lost to sea-level rise. Other sites, however, might also be lost or at least heavily damaged by changes in coastal geomorphology since erosion is ongoing, with at least $70 \%$ of sandy beaches around the world being recessional in nature (Zhang 2011:41). Using high-level LiDAR data Figure 6 shows areas of Bribie Island that would be inundated by $1 \mathrm{~m}$ and $2 \mathrm{~m}$ sea-level rises (Map 1 and 2) and also the level of detail that can be defined by using LiDAR data (Map 3). Figure 7 shows the level of detail that can be generated in 3D using LiDAR data.

LiDAR data when combined with archival aerial photographs, historical photographs and ground truthing can be used to identify and recover 'lost landscapes' (Randall 2014). LiDAR provides a snapshot of the ground surface at the time of collection but when combined with aerial photographs a model of past landscapes can be developed. LiDAR and additional tools such as the Digital Shoreline Analysis System (DSAS) can improve understanding of long-term geomorphic processes and allow for the analysis of beach micro-topography and quantification of local sediment budgets (Brock and Purkis 2009; Liu et al. 2007); the calculation of shoreline change (Gontz et al. 2011); and identification of potential flood prone areas (Brock and Purkis 2009). DSAS is 
computer software that computes rate-of-change statistics from multiple historic shoreline positions in GIS. It is also useful for computing rates of change for just about any other boundary change problem that incorporates a clearly identified feature position at discrete times (it is freely available for download at Woods Hole Science Center 2013). It could be used in areas where aerial photographs or satellite imagery are available over an extended period of time.

LiDAR has considerable potential to identify geomorphological landscape features and archaeological features at high levels of resolution. For example, after mapping $5.5 \%$ of the German state of BadenWürttemburg Hesse (2010:70) was able to identify 25,597 pre-modern anthropogenic features and potential archaeological sites compared with a previous record of 4,037. While LiDAR might be less successful in Australia due to the less structural nature of the archaeological record, features such as shell mounds, fish traps and historical sites could be identified. It would also be particularly useful in interpreting geomorphological changes in coastal areas and therefore assist in accounting for the presence or absence of sites.

\section{Discussion}

Early coastal dwellers had significant physical impacts in the coastal zone and on marine ecosystems (e.g. Erlandson and Rick 2010). Much of the evidence for this is locked up in coastal dunes. Coastal dunes, however, are fragile systems impacted by the dynamic nature of weather and wave climates and a complex range of human-induced impacts that occur on a number of timescales. The magnitude of these changes may also be largely random and unpredictable. Given the range of potential impacts that may occur on the coast it is critical that broad-scale and long-term monitoring is undertaken so that long- and short-term trends in a range of variables may be identified. Cultural heritage professionals need to continue to assess their expertise, and the extent of resources available to deal with these levels of change. In particular, there is a need to address the ability of professionals to design, implement and manage largescale salvage projects where loss of sites is likely. Strategies for responding to change need to be framed in terms of the uncertainty of potential global warming, the extent of normal variability in environmental factors, the impact of other perhaps more dominant human-induced changes and the concerns of heritage owners or users (Rowland 2008). Significantly, climate scientists have themselves noted an important shift in focus from assuming that climate change is the major cause of change in coastal environments to one in which there is a need to better understand climatic and non-climatic drivers and their interactions at different spatial and temporal scales (Brown et al. 2014).

Environmental changes and increasing human development in the coastal zone will continue to impact on coastal heritage places whether or not sea-levels change as a result of human-induced global warming. The potential impact of global warming should, however, heighten the need to continue to define and refine the processes impacting on coastal archaeological sites. The principal threats to heritage sites are the same as those endangering coastal morphology and related biodiversity

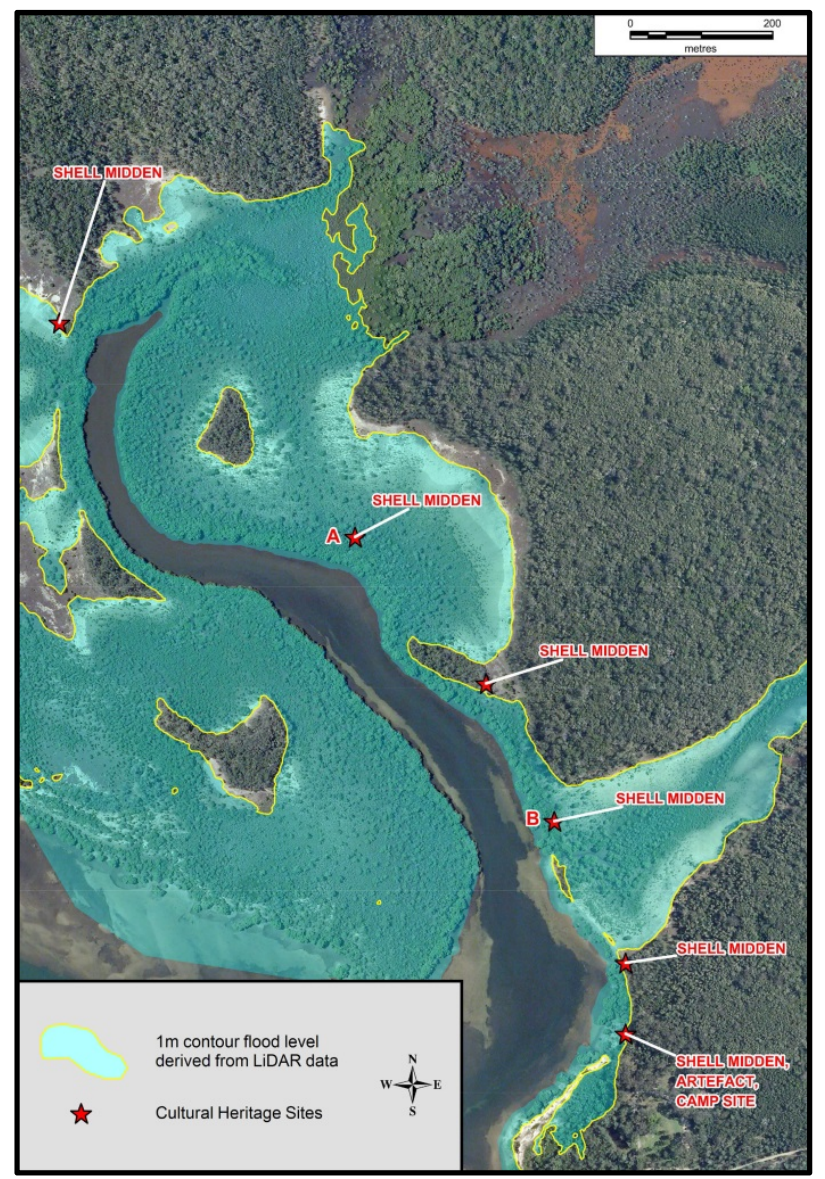

Figure 5. Potential impact of IPCC predicted $1 \mathrm{~m}$ sealevel rise on an area of Bribie Island (data supplied by Department of Natural Resources and Mines, The State of Queensland).

and cultural heritage managers should therefore become more involved on a multidisciplinary basis with scientists and planners dealing with these issues. Archaeology can provide unique data on the long-term environmental and cultural histories of coastal zones and the long-term impacts of people on marine resources and ecosystems. There is therefore a need to integrate archaeology into contemporary coastal research conducted by other scientists. Cultural heritage managers also need to align their research and planning policies with state planning policies and national coastal management plans (e.g. Department of Climate Change 2009) and with integrated coastal zone management (Norman 2009:298). There are a number of ways in which this can be achieved.

Firstly, the International Geosciences Programme (IGCP) of UNESCO and the INQUA Commission on Coastal and Marine Processes (CMP) has provided a framework for the worldwide exchange of scientific information and common research in sea-level change and coastal evolution (see Boski and Long 2010 for a brief introduction) and cultural heritage managers should be aware of these links and align their research and monitoring with these programmes.

Cultural heritage managers in Australia also need to establish new lines of communication between people working on coastal cultural heritage management. Currently there is no organised avenue for the sharing of information, in part, owing to the very different State and Commonwealth heritage jurisdictions. By way of comparison the federal United States National Park 


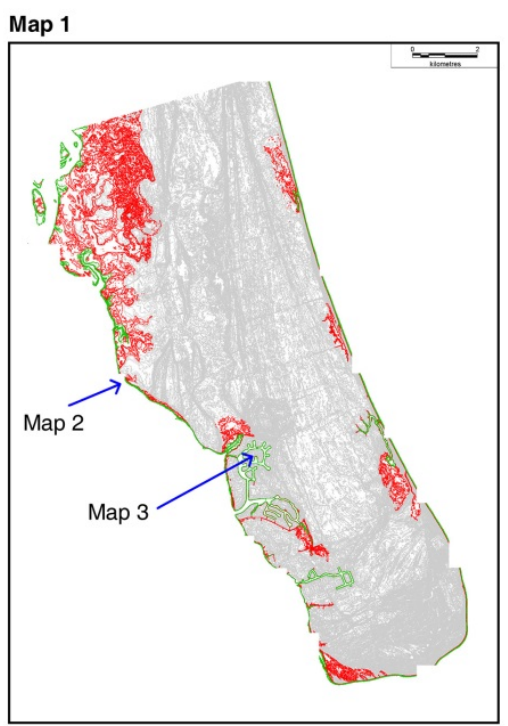

Areas of Bribie Island that will be subject to inundation as a result of $1 \mathrm{~m}$ and $2 \mathrm{~m}$ sea level rises

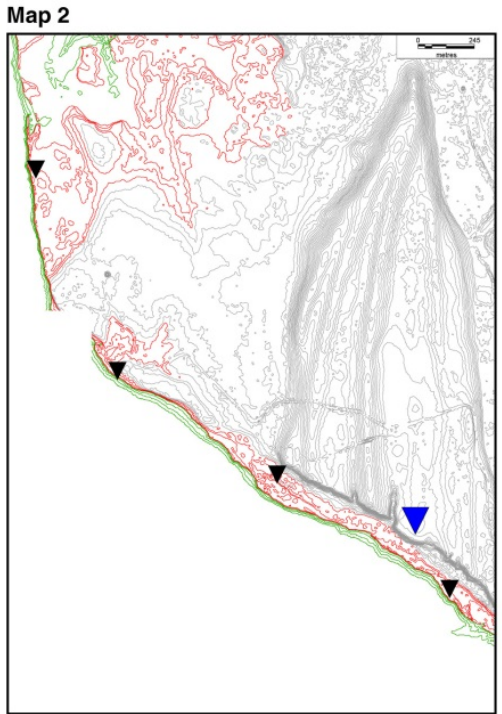

Cultural Heritage sites at risk from a $1 \mathrm{~m}$ and $2 \mathrm{~m}$ sea level rise

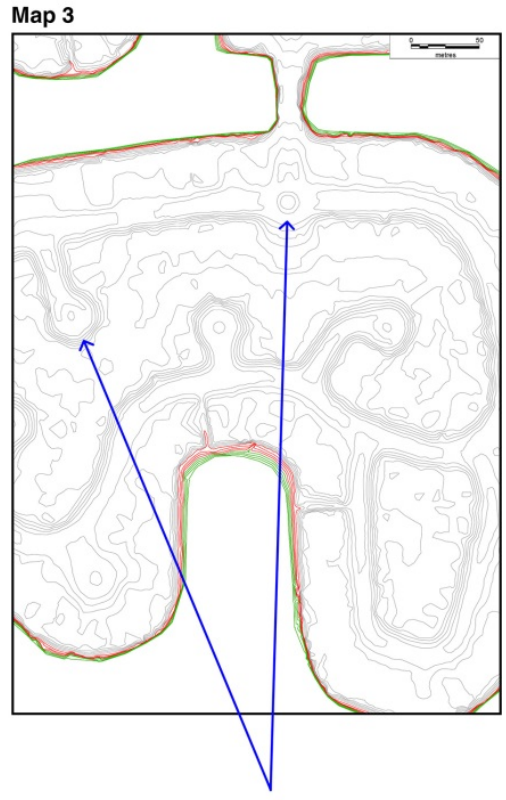

Cul de-sacs and roundabouts visible

Figure 6. LiDAR data for southern Bribie Island indicating high-level precision mapping (25cm contours) (data supplied by Department of Natural Resources and Mines, The State of Queensland).

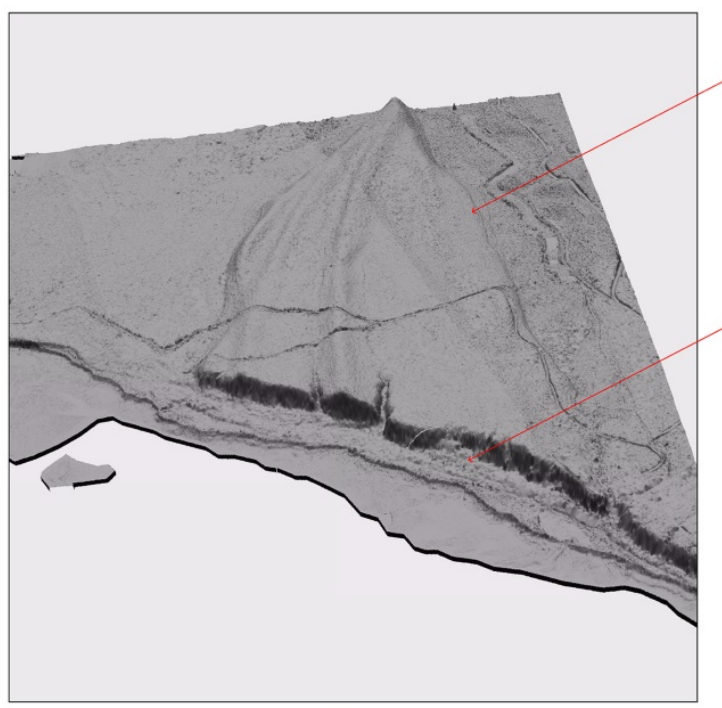

3D VIEW

MAP 2

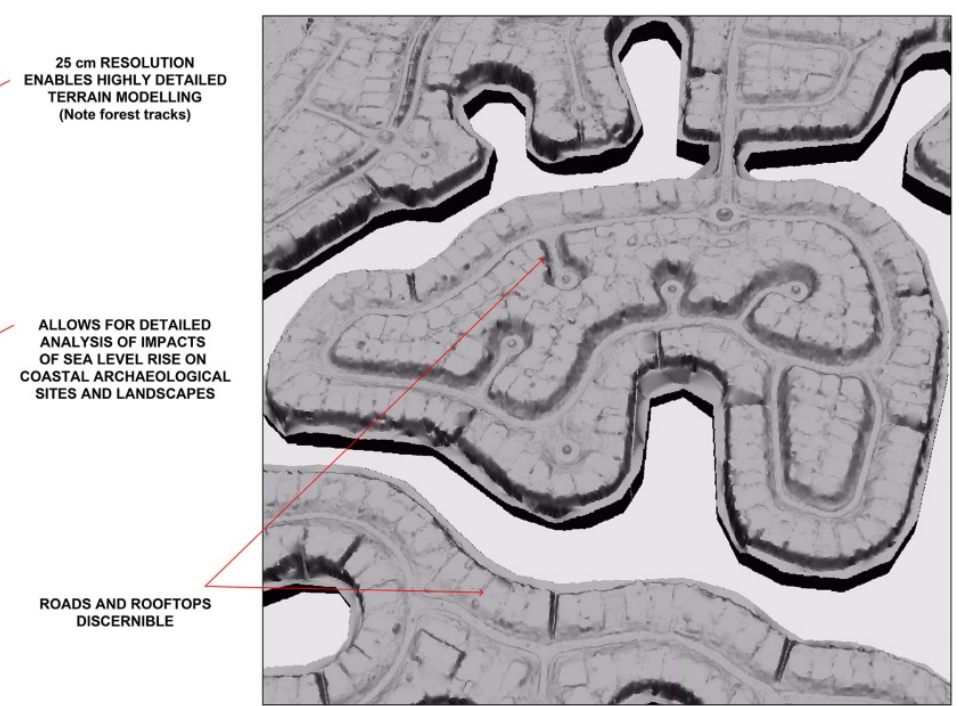

3D VIEW

MAP 3

Figure 7. LiDAR elevation models for Bribie Island (Figure 6, Maps 2 and 3) presented in 3D (data supplied by Department of Natural Resources and Mines, The State of Queensland). 
Service (NPS) has taken a lead in providing critical information regarding the protection of archaeological sites. Site preservation articles regularly appear in two widely distributed Park Service periodicals, the Federal Archaeological Report and CRM. The NPS Archaeological Assistance Program Technical Briefs series also includes issues on relevant site protection topics (e.g. Thorne 2004). The National Clearinghouse for Archaeological Site Stabilization (2010), a division of the Centre for Archaeological Research at the University of Mississippi, also serves as a source for technical support and training for in-place archaeological site stabilisation technologies. The Florida Department of State Division of Historical Resources (Florida Heritage 2004) also provides similar guidelines. The US Army Corps of Engineers, conducted several years of archaeological site preservation research which resulted in 55 technical notes comprising The Archaeological Sites Protection and Preservation Notebook. The technical notes cover several topics, including the nature of various impacts to archaeological sites and summary discussion of site protection projects from around the country. Although the research and development aspects of the Corps of Engineers have concluded, technical assistance is still available through the Center for Cultural Site Preservation Technology at the Waterways Experiment Station (Nickens 2001).

There is little doubt that detailed, long-term monitoring is the ideal way to obtain information about the current state of the environment, rates of change, and the appropriate management techniques required to deal with the changes. However, such monitoring is rare. Detailed monitoring is expensive and suffers from the reality that it is, in fact, long-term. Predictive modelling is also rare due to the uncertainty of many variables (e.g. Bernier et al. 2007; McInnes et al. 2003). Because of the expense and time-consuming nature of such monitoring it may be necessary to concentrate on areas of known significance and also to focus on digitising geoindicators so that long-term assessment and comparisons can be facilitated. It would be costly, time-consuming and impossible to maintain a comprehensive and sophisticated monitoring system for all coastal sites. Nevertheless, the approaches to monitoring outlined in this paper could be usefully developed in areas of development or high significance.

\section{Conclusion}

Anecdotal information can be used along with occasional observations to identify general trends in coastal change. Observations can be undertaken on an annual basis, but in the case of major climate events observations should follow as soon as practical after the event. Second, major projects could be developed that focus more broadly on coastal areas. This would require a risk management analysis of sections of the coast, mapping such factors as landform type, vegetation coverage, climate, storm surge, and predicted global sea-level rise. It would also involve mapping past and present impacts, such as past urban development, present and future development, and other coastal works, including mining, tourism, agricultural, and industrial developments. Third, at a broader scale, geoindicators could be mapped as indicators of trends in respect to potential global warming and other natural and human-induced changes (see also Rowland 2008). A series of risk assessment maps could then be produced for the coastline. Importantly, digital models of the coastline could also be developed that could be rapidly updated as new data become available. The application of LiDAR and other remote sensing techniques as briefly outlined in this paper have great potential both for predictive modelling and monitoring. With LiDAR use continuing to expand among a number of disciplines, a multidisciplinary approach to LiDAR data capture could become cost effective for archaeologists and cultural heritage managers seeking to monitor inundation risk and other changes to coastal heritage sites. We appreciate that the size of the Australian coastal zone and the multiplicity of heritage jurisdictions works against coordination of approaches to coastal cultural heritage management but recommend that a group be established to share information and discuss principles and guidelines on how we might better achieve monitoring and management of Australian coastal archaeological heritage.

Numerous cultural and environmental factors have impacted on coastal cultural heritage sites in Australia over a long period of time. More recently, human-induced global warming has become a focus of projected impacts on the coastline. However, we must not lose sight of the vast range of more immediate threats to coastal areas including those associated with population growth and economic development. Such a view has also recently been articulated by climate scientists (Brown et al. 2014). The threats to the coast can be identified by undertaking coastal monitoring using a range of information and techniques, from the anecdotal to the more complex as briefly outlined in this paper.

\section{Acknowledgements}

An early version of this paper was presented at the Australian Archaeological Association Annual Conference at Batemans Bay in December 2010 in a session titled 'Shifting Archaeology at the Shoreface: 21st Century Challenges for Investigating, Interpreting and Managing Coastal Archaeological Sites', convened by Tony Barham and Marjorie Sullivan. We thank them for the opportunity to present our initial thoughts on this topic. Thanks to John Ruffini, Director, Department of Science, Information Technology, Innovation and the Arts, Queensland Government for permission to reproduce Figure 2. We also thank the Department of Natural Resources and Mines (DNRM) Queensland for the supply and use of data in Figures 3 to 7. SU is the recipient of an Australian Research Council Future Fellowship (project number FT120100656). We also acknowledge the input of two referees in helping to improve this paper.

\section{References}

Aboriginal Affairs Victoria 2000 Conserving Aboriginal Places in Coastal Victoria. Melbourne: Aboriginal Affairs Victoria.

Abuodha, P.A.O. and C.D. Woodroffe 2010 Assessing vulnerability to sea-level rise using a coastal sensitivity index: A case study from southeast Australia. Journal of Coastal Conservation 14(3):189-205.

Akumu, C.E., S. Pathirana, S. Baban and D. Bucher 2010 Examining the potential impacts of sea level rise on coastal wetlands in north-eastern NSW, Australia. Journal of Coastal Conservation 15(1):15-22.

ANU Heritage 2007 Nundera Point Midden Conservation Project. Retrieved 21 June 2010 from http://heritage.anu.edu.au/?pid=44. 
Bailey, G. 2004 World prehistory from the margins: The role of coastlines in human evolution. Journal of Interdisciplinary Studies in History and Archaeology 1(1):39-50.

Bennett, R., K. Welham, R.A. Hill and A. Ford 2012 A comparison of visualisation techniques for models created from airborne laser scanned data. Archaeological Prospection 19(1):41-48.

Berger, A.R. and W.J. Iams (eds) 1996 Geoindicators: Assessing Rapid Environmental Changes in Earth Systems. Rotterdam: A.A. Balkema.

Bernardini, F., A. Sgambati, M. Montagnari Kokelj, C. Zaccaria, R. Micheli, A. Fragiacomo, C. Tiusse, D. Dreossi, C. Tuniz and A. De Min 2013 Airborne LiDAR application to karstic areas: The example of Trieste province (north-eastern Italy) from prehistoric sites to Roman forts. Journal of Archaeological Science 40:2152-2160.

Bernier, N.B., K.R. Thompson, J. Ou and H. Ritchie 2007 Mapping the return periods of extreme sea levels: Allowing for short sea level records, seasonality, and climate change. Global and Planetary Change 57:139-150.

Bhattacharyya, R., M.A. Fullen, K. Davies and C.A. Booth 2010 Use of palm-mat geotextiles for rainsplash erosion control Geomorphology 119:52-61.

Bird, M. 1992 The impact of tropical cyclones on the archaeological record: An Australian example. Archaeology in Oceania 27(2):75-86.

Bird, M. 1995 Coastal morphodynamics and the archaeological record: Further evidence from Upstart Bay, north Queensland. Australian Archaeology 40:57-58.

Bonhomme, T. and S. Buzer 1994 Holocene Shell Middens of the Central Coast of New South Wales: An Investigation of the Management Problems Concerning Coastal Shell Middens. Unpublished report to New South Wales National Parks and Wildlife Service, Sydney.

Boski, T. and A.J. Long 2010 Quaternary land-ocean interactions: Driving mechanisms and coastal responses. Quaternary International 221:1-2.

Britsch, L.D. and L.M. Smith 1989 Geomorphic investigation of the Terrebonne Marsh, Louisiana: Foundation for cultural resource surveys. Geoarcheology 4(3):229-250.

Brock, J.C. and S.J. Purkis 2009 The emerging role of Lidar remote sensing in coastal research and resource management. Journal of Coastal Research Special Issue 53:1-5.

Brown, S., R.J. Nicholls, S. Hanson, G. Brundrit, J.A. Dearing, M.E. Dickson, S.L. Gallop, S. Gao, I.D. Haigh, J. Hinkel, J.A. Jiménez, R.J.T. Klein, W. Kron, A.N. Lázár, C.F. Neves, A. Newton, C. Pattiaratachi, A. Payo, K. Pye, A. Sánchez-Arcilla, M. Siddall, A. Shareef, E.L. Tompkins, A.T. Vafeidis, B. van Maanen, P.J. Ward and C.D. Woodroffe 2014 Shifting perspectives on coastal impacts and adaptation. Nature Climate Change 4:752-755.

Bull, J.M., H. Miller, D.M. Gravley, D. Costello, D.C.H. Hikuroa and J.K. Dix 2010 Assessing debris flows using LIDAR differencing: 18 May 2005 Matata event, New Zealand. Geomorphology 124:75-84.

Cane, S. 1997 A Coastal Heritage: A Review of Indigenous Sites on the Australian Coastline. Unpublished report to Australian Heritage Commission, Canberra.

Challis, K., C. Carey, M. Kincey and A.J. Howard 2011a Airborne Lidar intensity and geoarchaeological prospection in river valley floors. Archaeological Prospection 18(1):113.

Rowland, Ulm \& Roe
Challis, K., P. Forlin and M. Kincey 2011b A generic toolkit for the visualization of archaeological features on airborne LiDAR elevation data. Archaeological Prospection 18:279289.

Chase, A.F., D.Z. Chase, J.F. Weishampel, J.B. Drake, R.L. Sherstha, K.C. Slatton, J.J. Awe and W.E. Carter 2011 Airborne LiDAR, archaeology, and the ancient Maya landscape at Caracol, Belize. Journal of Archaeological Science 38:387-398.

Church, J.A. and N.J. White 2006 A 20th century acceleration in global sea-level rise. Geophysical Research Letters 33(1):L01602

Church, J.A., N.J. White, T. Aarup, W. Stanley Wilson, P.L. Woodworth, C.M. Domingues, J.R. Hunter and K. Lambeck 2008b Understanding global sea levels: Past, present and future. Sustainable Science 3:9-22.

Church, J.A., N.J. White, J.R. Hunter and K. Lambeck 2008a Briefing: A Post-IPCC AR4 Update on Sea-Level Rise. Hobart: Antarctic Climate and Ecosystems Cooperative Research Centre. Retrieved 20 June 2010 from http://www.acecrc.org.au.

Clark, P. and J. Hope 1985 Aboriginal burials and shell middens at Snaggy Bend and other sites on the central Murray River. Australian Archaeology 20:68-89.

Coetzee, I. and J. Kaplan 1996 Coastal dunes and the state of archaeological information. Landscape and Urban Planning 34:361-365

Commonwealth of Australia 2010 Australia to 2050: Future Challenges. Canberra: Attorney-General's Department, Commonwealth of Australia. Retrieved 8 January 2013 from http://archive.treasury.gov.au/igr/igr2010/Overview/pdf/IGR _2010_Overview.pdf.

Corns, A. and R. Shaw 2009 High resolution 3-dimensional documentation of archaeological monuments \& landscapes using airborne LiDAR. Journal of Cultural Heritage 10S:e72-e77.

Cowell, P.J., B.G. Thom, R.A. Jones, G.H. Everts and D. Simanovic 2006 Management of uncertainty in predicting climate-change impacts on beaches. Journal of Coastal Research 22(1):232-245.

Crowell, M., S.P. Leatherman and M.K. Buckley 1991 Historical shoreline change: Error analysis and mapping accuracy. Journal of Coastal Research 7(3):839-852.

CSIRO 2013 Light detection and ranging (lidar). Retrieved 8 January 2013 from http://www.csiro.au/Outcomes/Foodand-Agriculture/LightDetectionLidar.aspx.

Daly, C. 2011 The potential for indicators in the management of climate change impacts on cultural heritage. In: Cultural Heritage Preservation; Proceedings of the European Workshop on Cultural Heritage Preservation. EWCHP 2011, Berlin, Germany, September 26 to 28. Retrieved 8 January 2013 from http://arrow.dit.ie/cgi/viewcontent.cgi? article $=1006 \&$ context $=$ beschreccon .

Davis, J.E., S.T. Maynord, J. McCormick and T.J. Olin 2000 Shoreline protection and erosion control. US Army Corps of Engineers. In D.F. Hayes, T.J. Olin and J.C. Fischenich (eds), Wetlands Engineering Handbook, Section 5-32. Engineer Research and Development Center, US Army Corps of Engineers. Retrieved 8 January 2013 from http://el.erdc.usace.army.mil/elpubs/pdf/wrpre21/sec5.pdf.

Department of Climate Change 2009 Climate Change Risks to Australia's Coast: A First Pass National Assessment. Canberra: Commonwealth of Australia. 
Department of Resources, Energy and Tourism 2010 Coastline Lengths. Retrieved 4 March 2013 from http://www.ga.gov.au/education/geoscience-basics/ dimensions/coastline-lengths.html.

Erlandson, J.M. and T.C. Rick 2010 Archaeology meets marine ecology: The antiquity of maritime cultures and human impacts on marine fisheries and ecosystems. Annual Review of Marine Science 2:231-251.

FitzGerald, D.M., M.S. Fenster, B.A. Argow and I.V. Buynevich 2008 Coastal impacts due to sea-level rise. Annual Review of Earth and Planetary Sciences 36:601-647.

Fitzpatrick, S.M., M. Kappers and Q. Kaye 2006 Coastal erosion and site destruction on Carriacou, West Indies. Journal of Field Archaeology 31(3):251-262.

Florida Heritage 2004 Archaeological Stabilization Guide: Case Studies in Protecting Archaeological Sites. Retrieved 3 January 2013 from http://dos.myflorida.com/media/ 30913/stab_guide.pdf.

Forbes, D.L. and D.G.E. Liverman 1996 Geological indicators in the coastal zone. In A.R. Berger and W.J. Iams (eds), Geoindicators: Assessing Rapid Environmental Changes in Earth Systems, pp.175-192. Rotterdam: A.A Balkema.

Gesch, D.B. 2009 Analysis of Lidar elevation data for improved identification and delineation of lands vulnerable to sealevel rise. Journal of Coastal Research Special Issue 53:4958.

Ghilardi, M. and S. Desruelles 2008 Geoarchaeology: Where human, social and earth sciences meet with technology. Sapiens 1(2):1-9.

Gontz, A.M., C.V. Maio, E.K. Wagenknecht and E.P. Berkland 2011 Assessing threatened coastal sites: Applications of ground-penetrating radar and geographic information systems. Journal of Cultural Heritage 12(2):451-458.

Hamel, G. and K. Jones 1982 Manual of Vegetation Management on New Zealand Archaeological Sites. Wellington: New Zealand Historic Places Trust.

Hassler, U. 2006 Implications of climate change on heritage. Building Research and Information 34(2):175-179.

Hesse, R. 2010 LiDAR-derived local relief models - A new tool for archaeological prospection. Archaeological Prospection 17(2):67-72.

Hugenholtz, C.H., N. Levin, T.E. Barchyn and M.C. Baddock 2012 Remote sensing and spatial analysis of aeolian sand dunes: A review and outlook. Earth-Science Reviews 111:319-334.

Hunter, J. 2010 Estimating sea-level extremes under conditions of uncertain sea-level rise. Climatic Change 99:331-350.

Irvine-Fynn, T.D.L., N.E. Barrand, P.R. Porter, A.J. Hodson and T. Murray 2011 Recent high-Arctic glacial sediment redistributions: A process perspective using airborne Lidar. Geomorphology 125:27-39.

Johnson, K.M. and W.B. Quimet 2014 Rediscovering the lost archaeological landscape of southern New England using airborne light detection and ranging (LiDAR). Journal of Archaeological Science 43:9-20.

Jones, K.L. 2003 Advances and issues in prehistoric archaeological site stabilisation. Bulletin of the Indo-Pacific Prehistory Association 23:191-200.
Kerfoot, W.C., F. Yousef, S.A. Green, R. Regis, R. Shuchman, C.N. Brooks, M. Sayers, B. Sabol and M. Graves 2012 Light detection and ranging (LiDAR) and multispectral studies of disturbed Lake Superior coastal environments. Limnology and Oceanography 57(3):749-771.

Kvamme, K.L. 1999 Recent directions and developments in geographical information systems. Journal of Archaeological Research 7(2):153-201.

Ladefoged, T.N., M.D. McCoy, G.P. Asner, P.V. Kirch, C.O. Puleston, O.A. Chadwick and P.M. Vitoustek 2011 Agricultural potential and actualised development in Hawai'i: An airborne LiDAR survey of the leeward Kohala field systems (Hawai'i Island). Journal of Archaeological Science 38:3605-3619.

Lewis, R.B. 2000 Sea-level rise and subsidence effects on Gulf Coast archaeological site distributions. American Antiquity 65(3):525-541.

Liu, H., D. Sherman and S. Gu 2007 Automated extraction of shorelines from airborne light detection and ranging data and accuracy assessment based on Monte Carlo simulation. Journal of Coastal Research 23(6):1359-1369.

Lynott, M.J. 1989 Stabilization of shoreline archaeological sites at Voyageurs National Park. American Antiquity 54(4):792801.

Macphail, R.I., M.J. Allen, J. Crowther, G.M. Cruise and J.E. Whittaker 2010 Marine inundation: Effects on archaeological features, materials, sediments and soils. Quaternary International 214:44-55.

Maio, C.V., A.M. Gontz, D.E. Tenenbaum and E.P. Berkland 2012 Coastal hazard vulnerability assessment of sensitive historical sites on Rainsford Island, Boston Harbour, Massachusetts. Journal of Coastal Research 28(1A):20-33.

McInnes, K.L., K.J.E. Walsh, G.D. Hubbert and T. Beer 2003 Impact of sea-level rise and storm surges on a coastal community. Natural Hazards 30:187-207.

McInnes, K.L., I. Macadam, G. Hubbert and J. O’Grady 2013 An assessment of current and future vulnerability to coastal inundation due to sea-level extremes in Victoria, southeast Australia. International Journal of Climatology 33(1):33-47.

McIntyre-Tamwoy, S. and A .Buhrich 2012 Lost in the wash: Predicting the impact of losing Aboriginal coastal sites in Australia. The International Journal of Climate Change: Impacts and Responses 3(1):53-66.

Moore, L.J. 2000 Shoreline mapping techniques. Journal of Coastal Research 16(1):111-124.

National Clearinghouse for Archaeological Site Stabilisation 2010 Managing Archaeological Resources through in-situ Stabilisation and Conservation. Retrieved 4 May 2010 from http://www.nps.gov/history/seac/stabil-clearinghouse.htm4/ 05/2010.

Nicholls, R.J. 2002 Rising sea levels: Potential impacts and responses. In R. Hester and R.M. Harrison (eds), Global Environmental Change, pp.83-107. Issues in Environmental Science and Technology 17. Cambridge: Royal Society of Chemistry.

Nickens, P.R. 2001 Technologies for in-place protection and long-term conservation of archaeological sites. Archives and Museum Informatics 13:383-405. 
Norman, B. 2009 Principles for an intergovernmental agreement for coastal planning and climate change in Australia. Habitat International 33:293-299.

Oskin, M.E., J.R. Arrowsmith, A.H. Corona, A.J. Elliot, J.M. Fletcher, E.J. Fielding, P.O. Gold, J.J.G. Garcia, K.H. Hudnut, J. Liu-Zeng and O.J. Teran 2012 Near-field deformation from the El Mayor-Cucapah earthquake revealed by differential LIDAR. Science 335:702-705.

Parry, M., O. Canziani, J. Palutikof, P. van der Linden and C. Hanson 2007 Climate Change 2007: Impacts, Adaptation and Vulnerability: Contribution of Working Group II to the Fourth Assessment Report of the Intergovernmental Panel on Climate Change. Cambridge: Cambridge University Press.

Pearce, H. 2006 Cyclone Larry North Queensland Audit of Damaged Heritage and Community Buildings. Unpublished report to Environmental Protection Agency, Brisbane.

Ponosov, V.V. 1964 Results of an Archaeological Survey of the Southern Region of Moreton Bay and of Moreton Island (1963-1964). Unpublished report to Department of Psychology, University of Queensland.

Przywolnick, K. 2002 Coastal sites and severe weather in Cape Range Peninsula, northwest Australia. Archaeology in Oceania 37(3):137-152.

Queensland Climate Change Centre of Excellence 2011 Queensland Coastal Processes and Climate Change. Brisbane: Department of Environment and Resource Management.

Randall, A.R. 2014 LiDAR-aided reconnaissance and reconstruction of lost landscapes: An example of freshwater shell mounds (ca. 7500-500 CAL B.P.) in northeastern Florida. Journal of Field Archaeology 39(2):162-179.

Reeves, D.M. 1936 Aerial photography and archaeology. American Antiquity 2(2):102-107.

Revell, D.L., P.D. Komar and A.H. Sallenger Jr. 2002 An application of LIDAR to analyses of El Niño erosion in the Netarts Littoral Cell, Oregon. Journal of Coastal Research 18(4):792-801.

Risbøl, O., C. Briese, M. Doneus and N. Nesbakken in press Monitoring cultural heritage by comparing DEMs derived from historical aerial photographs and airborne laser scanning. Journal of Cultural Heritage doi:10.1016/j.culher.2014.04.002.

Rowland, M.J. 2008 Saving the past from the future. Historic Environment 21:9-29.

Rowland, M.J. 2010 Will the sky fall in? Global warming an alternative view. Antiquity 84:1163-1171.

Rowland, M.J. and S. Ulm 2012 Key issues in the conservation of the Australian coastal archaeological record: Natural and human impacts. Journal of Coastal Conservation 16(2):159171.

Sallenger Jr. A.H., W.B. Krabill, R.N. Swift, J. Brock, J. List, M. Hansen, R.A. Holman, S. Manizade, J. Sontag, A. Meredith, K. Morgan, J.K. Yunkel, E.B. Frederick and H. Stockdon 2003 Evaluation of airborne topographic Lidar* for quantifying beach changes. Journal of Coastal Research 19(1):125-133

Short, A.D. and C. D. Woodroffe 2009 The Coast of Australia. Cambridge: Cambridge University Press.
Shrestha, R.L., W.E. Carter, M. Sartori, B.J. Luzum and K.C. Slatton 2005 Airborne laser swath mapping: Quantifying changes in sandy beaches over time scales of weeks to years. ISPRS Journal of Photogrammetry \& Remote Sensing 59:222-232.

Smith, A. 1998 Preliminary results of a midden excavation at Arrawarra Beach, mid-north coast NSW. Australian Archaeology 47:61-62.

Snelson W.J., M.E. Sullivan and N.D. Preece 1986 Nundera Point - An experiment in stabilising a foredune shell midden. Australian Archaeology 23:25-41.

Stevens, A. and L. Collins 2011 Development and application of GIS datasets for assessing and managing coastal impacts and future change on the central coast of Western Australia. Journal of Coastal Conservation 15:671-685.

Stockdon, H.F., A.H. Sallenger Jr., J.H. List and R.A. Holman 2002 Estimation of shoreline position and change using airborne topographic Lidar data. Journal of Coastal Research 18(3):502-513.

Stockton, J. 1973 Report of an Archaeological Survey in the Vicinity of Bribie Island, South-East Queensland. Unpublished BA (Hons) thesis, University of Queensland, Brisbane.

Sullivan, M.E. 1989 Recording shell midden sites. In J. Flood, I. Johnson and S. Sullivan (eds), Sites and Bytes: Recording Aboriginal Places in Australia, pp.49-53. Special Australian Heritage Publication Series 8. Canberra: Australian Government Publishing Service.

The Getty Conservation Institute 2003 The GCI Project Bibliographies Series: Conservation and Management of Archaeological Sites. Retrieved 3 January 2013 from http://www.getty.edu/conservation/resources/archaeology_bi b.pdf.

Thieler, E.R. and W.W. Danforth 1994a Historical shoreline mapping (I): Improving techniques and reducing positioning errors. Journal of Coastal Research 10(3):549-563.

Thieler, E.R. and W.W. Danforth 1994b Historical shoreline mapping (II): Application of the Digital Shoreline Mapping and Analysis Systems (DSMS/DSAS) to shoreline change mapping in Puerto Rico. Journal of Coastal Research 10(3):600-620.

Thorne, M. 2004 Technical Brief 18: Protecting Archaeological Sites on Eroding Shorelines: A Hay Bales Approach. Washington, D.C.: DOI Departmental Consulting Archaeologist/NPS Archaeology Program, National Park Service. Retrieved 3 January 2013 from http://www.nps.gov./archeology/pubs/techBr/TCH18.htm.

Turnbaugh, W.A. 1978 Floods and archaeology. American Antiquity 43(4):593-607.

Ulm, S. 2011 Coastal foragers on southern shores: Marine resource use in northeast Australia since the late Pleistocene. In N.F. Bicho, J.A. Haws and L.G. Davis (eds), Trekking the Shore: Changing Coastlines and the Antiquity of Coastal Settlement, pp.441-461. New York: Springer.

Verhoeven, G., M. Doneus, C. Briese and F. Vermeulen 2012 Mapping by matching: A computer vision-based approach to fast and accurate georeferencing of archaeological aerial photographs. Journal of Archaeological Science 39:20602070. 
Voice, M., N. Harvey and K. Walsh 2006 Vulnerability to Climate Change of Australia's Coastal Zone: Analysis of Gaps in Methods, Data and System Thresholds. Unpublished report to Australian Greenhouse Office, Canberra.

Watson, W. 1993 The Volatile Midden: The Depositional and Post-Depositional Alteration to Australian Coastal Shell Middens. Unpublished BA (Hons) thesis, Department of Archaeology, La Trobe University, Bundoora.

White, S.A. and Y. Wang 2003 Utilizing DEMs derived from LIDAR data to analyze morphologic change in the North Carolina coastline. Remote Sensing of Environment 85:3947.

Williams, D.M. 2004 Short contribution: Marine erosion and archaeological landscapes: A case study of stone forts at cliff-top locations in the Aran Islands, Ireland. Geoarchaeology 19(2):167-175.

Woods Hole Science Center 2013 Digital Shoreline Analysis. Retrieved 8 January 2013 from http://woodshole.er. usgs.gov/project-pages/dsas/.
Yang, Z. and J.T. Teller 2012 Using LiDAR digital elevation model data to map Lake Agassiz beaches, measure their isostactically-induced gradients, and estimate their ages. Quaternary International 260:32-42.

Yousef, F., W.C. Kerfoot, C.N. Brooks, R. Shuchman, B. Sabol and M. Graves 2013 Using LiDAR to reconstruct the history of a coastal environment influenced by legacy mining. Journal of Great Lakes Research http://dx.doi.org/ 10.1016/j.jglr.2013.01.003.

Zallar S.A., K. Siow and P.J.F. Coutts 1979 Stabilisation of Coastal Archaeological Sites in Victoria: A Pilot Study. Melbourne: Soil Conservation Authority and Victoria Archaeological Survey, Ministry for Conservation.

Zhang, K. 2011 Analysis of non-linear inundation from sealevel rise using LIDAR data: A case study for South Florida. Climatic Change 106(4):537-565.

Zhang, K., B.G. Douglas and S.P. Leatherman 2004 Global warming and coastal erosion. Climatic Change 64:41-58. 